\title{
Effect of Return on Equity, Debt to Equity Ratio and Current Ratio to Stock Returns in Large Trading Companies Listed on the Indonesia Stock Exchange 2016-2018 Period
}

\author{
Fenny $^{1}$, Yusuf Ronny Edward ${ }^{2}$ \\ ${ }^{1,2}$ Universitas Prima Indonesia \\ Corresponding Author: Fenny
}

\begin{abstract}
This study aims to examine the effect of return on equity, debt to equity ratio, and current ratio on stock returns. Several previous studies regarding stock returns show different results. Therefore, other research needs to be done to retest stock returns. The population of this study is the large trading companies listed on the Indonesia Stock Exchange (BEI) 2016-2018. Based on the purposive sampling method in the data collection process, obtained 14 companies as samples. The research variables used are return on equity (ROE), debt to equity ratio (DER), current ratio (CR), and stock returns. Hypothesis testing was carried out by multiple linear regression analysis using the Statistical Package for Social Science (SPSS) program version 21.0. The results showed that partially, ROE and DER had a significant effect on stock returns, while the CR had no significant effect on stock returns.
\end{abstract}

Keywords: Return on Equity, Debt to Equity Ratio, Current Ratio, Stock Returns

\section{INTRODUCTION}

Investment is a commitment to a number of funds or other resources carried out at this time, with the aim of obtaining a number of benefits in the future. One of the aspects assessed by investors is financial performance. In principle, the better the performance of the company will increase the demand for the company's shares, so that in turn it will also increase the company's stock price. Many people choose to invest their money, either in the form of investing in gold, houses or stocks.

This stock return can be used as an indicator of trading activities in the capital market. Basically, the return value of each security differs from one another. The return of a security is determined by many things such as the company's performance and the company's strategy to manage its profits.

Income from stock investment or return can be in the form of dividends and capital gains. Dividends are receipts from companies that come from distributed profits, while capital gains are income earned from the difference in share prices. If the price difference is negative, it means that investors experience capital loss and vice versa.

Investors often want immediate profits so they prefer capital gains rather than dividends.

In the capital market, not all shares of companies that have good profits will provide good returns to investors, so a more in-depth analysis of the company is needed. A company may experience fluctuating returns at any time due to various factors, both micro and macro.

Based on the description above, the researcher is interested in conducting research on this problem with the title "Effect of Return on Equity, Debt to Equity Ratio and Current Ratio to Stock Returns in 
Large Trading Companies Listed on the Indonesia Stock Exchange 2016-2018 Period."

\section{LITERATURE REVIEW Stock Returns}

According to Dwialesi and Darmayanti (2016), stock return is the rate of return obtained by investors from investment activities and is expressed in units.

Stock returns are the results obtained by investors from investing activities and are expressed in units. Stock returns consist of two components, namely capital gains and dividends.

According to Purnamasari, et al (2014), stock returns are formulated:

Stock Returns $=($ Pt- $($ Pt-1) $) /(($ Pt-1 $))$

Information:

$\mathrm{Pt}=$ Share price (closing price) period $\mathrm{t}$ (current).

Pt-1=The closing price of the previous period $(\mathrm{t}-1)$.

\section{Return on Equity}

According to Aisah and Mandala (2016), return on equity is a profitability ratio that describes the company's ability to provide benefits for common shareholders (capital owners) by showing the percentage of net profit available for shareholder capital that the company has used.

Return on equity is a profitability ratio that measures a company's ability to generate profits by showing the percentage of net income available for shareholder capital.

According to Anugrah and Syaichu (2016), return on equity can be measured using the formula:

\section{ROE $=($ Net Income $) /$ Equity}

\section{Debt to Equity Ratio}

According to Alipudin and Oktaviani (2016), debt to equity ratio (DER) is a ratio used to assess debt to equity. This ratio is used to determine the amount of funds provided by the borrower (creditor) and the owner of the company.
Debt to equity ratio (DER) is a ratio used to determine a company's ability to meet its obligations which is calculated by dividing total debt by equity.

According to Dewi and Suaryana (2013), DER can be calculated using the formula:

\section{Debt to Equity Ratio = (Total Debt)/(Total Equity) X 100\%}

\section{Current Ratio}

According to Erari (2014), current ratio is a ratio used to measure the level of liquidity. Liquidity shows the company's ability to pay financial obligations to pay short-term financial obligations on time.

Current Ratio is the ratio used to measure the level of liquidity to determine the company's ability to pay off its shortterm obligations.

According to Dewi and Suaryana (2013), the current ratio can be calculated using the formula:

\section{Current Ratio $=$ (Current Assets)/(Current Liabilities) X 100\%}

\section{Effect of Return on Equity on Stock Returns}

The ROE level has a positive relationship with stock prices, so the greater the ROE the greater the stock price, because the large ROE indicates that the returns that investors will receive will be high so that investors will be interested in buying these shares, and this causes the stock market price to tend to ride.

According to Dewi and Suaryana (2013), the higher the value of ROE, the more efficient the company (issuer) uses its own capital to generate profits for the company. Companies that are increasingly efficient in using their own capital to generate profits will give hope of an increase in stock returns.

The results of Yulianti and Suratno's research (2015) show that the variable return on equity partially has a positive and significant effect on stock returns. This shows that the amount of return on equity in property and real estate companies has a 
significant effect on stock returns, and indicates that investors view return on equity as having a role in making investment decisions.

According to the theory above, it is assumed that ROE has an influence on stock returns. The higher the ROE value tends to increase the stock return value.

\section{Effect of Debt to Equity Ratio on Stock Returns}

The higher the DER value, the lower the interest of investors who want to invest in the company, this can be seen from the low stock price, which causes the stock return of the company to be lower.

According to Siburian and Daulay (2013), Debt to Equity Ratio is a ratio that shows the relationship between total liabilities and total equity provided by the company owner. The higher the DER, the greater the company's liabilities compared to the equity owned by the company. The higher the DER tends to decrease returns stock, because the higher the level of debt indicates the company's interest expense will be greater and reduce profits.

The research results of Siburian and Daulay (2013) show that the Debt to Equity Ratio has a significant (significant) effect on the Return of Capital in banking companies listed on the Indonesia Stock Exchange.

Based on the theory above, it is assumed that DER has a negative relationship with stock returns, because the higher the DER value tends to decrease the value of stock returns, and vice versa.

\section{Effect of Current Ratio on Stock Returns}

A low current ratio is usually considered to indicate problems in liquidity, on the other hand, a current ratio that is too high is also not good, because it shows the large number of idle funds that can reduce the company's profitability. For this reason, a good current ratio is in accordance with the portion so that it can increase stock returns.
According to Syaichu (2017), a company that has a high Current Ratio value indicates that the company has a good performance based on current assets compared to its liabilities. Current assets that are higher than the debt are able to get high profits, so that the company will provide high returns for investors. Therefore, a high $\mathrm{CR}$ is very influential on stock returns.

The research results of Purnamasari et al. (2014) show that the current ratio has an effect on stock returns. The greater the ratio of assets to current debt, the higher the company's ability to cover its short-term liabilities.

From the theory above, it is assumed that the current ratio can affect stock returns because the high value of the current ratio indicates that the company has high profits so that it can increase stock returns.

\section{RESEARCH METHODS}

This research was conducted on the Indonesia Stock Exchange through the internet media, namely the official website of the IDX with the website address www.idx.co.id. The population in this study were large trading companies listed on the Indonesia Stock Exchange from 2016-2018, totaling 14 companies. Company data that can be used as a sample is 14 companies, while the data used in this study are 42 data taken from a sample of 14 companies multiplied by 3 research periods.

This study uses financial reports from 2016-2018 to see return on equity, debt to equity ratio, current ratio and stock returns. The dependent variable in this study is stock returns (Y). The independent variables in this study are return on equity (X1), debt to equity ratio (X2), and current ratio (X3).

Operational identification and definition are descriptions of the variables that have been selected and are described in Table 1. 
Fenny et.al. Effect of return on equity, debt to equity ratio and current ratio to stock returns in large trading companies listed on the Indonesia stock exchange 2016-2018 period.

Table 1. Operational Identification and Definition

\begin{tabular}{|c|c|c|c|}
\hline Variable & Definition & Indicator & Scale \\
\hline $\begin{array}{l}\text { Stock } \\
\text { Returns (Y) }\end{array}$ & $\begin{array}{l}\text { Stock returns are the results obtained by investors from investing } \\
\text { activities and are expressed in units. }\end{array}$ & $\begin{array}{l}\text { Stock Returns }=\frac{\mathrm{Pt}-(\mathrm{Pt}-1)}{(\mathrm{Pt}-1)} \\
\text { Source: Jogiyanto }(2013) \text { in Dwialesi and } \\
\text { Darmayanti (2016) }\end{array}$ & Ratio \\
\hline $\begin{array}{l}\mathrm{ROE} \\
\left(\mathrm{X}_{1}\right)\end{array}$ & $\begin{array}{l}\text { Return on equity is a profitability ratio that measures a company's } \\
\text { ability to generate profits by showing the percentage of net income } \\
\text { available for shareholder capital. }\end{array}$ & $\begin{array}{l}\text { ROE }=\frac{\text { Net Income }}{\text { Equity }} \\
\text { Source: Anugrah and Syaichu (2016) }\end{array}$ & Ratio \\
\hline $\begin{array}{l}\mathrm{DER} \\
\left(\mathrm{X}_{2}\right)\end{array}$ & $\begin{array}{l}\text { Debt to equity ratio (DER) is a ratio used to determine a } \\
\text { company's ability to meet its obligations which is calculated by } \\
\text { dividing total debt by equity. }\end{array}$ & $\begin{array}{l}\text { DER }=\frac{\text { Total Debt }}{\text { Total Equity }} \text { X 100\% } \\
\text { Source: Dewi and Suaryana (2013) }\end{array}$ & Ratio \\
\hline $\begin{array}{l}\mathrm{CR} \\
\left(\mathrm{X}_{3}\right)\end{array}$ & $\begin{array}{l}\text { Current ratio is a ratio used to measure the level of liquidity to } \\
\text { determine the company's ability to pay off its short-term } \\
\text { obligations. }\end{array}$ & $\begin{array}{l}\text { Current Ratio }=\frac{\text { Current Assets }}{\text { Current Liabilities }} \mathrm{X} \\
100 \% \\
\text { Source: Anugrah and Syaichu (2016) }\end{array}$ & Ratio \\
\hline
\end{tabular}

This research is a quantitative study that uses or collects financial statement data downloaded from the Indonesia Stock Exchange website. The data will be tested using multiple linear regression because the independent and dependent variables used in this study use the ratio variable.

\section{RESULT AND DISCUSSION}

Wholesalers or distributors are traders who buy goods in large quantities directly from their producers to be resold to retailers or to industrial companies

\section{Classical Assumption Test Results Normality Test}

The normality test aims to test whether in the regression model, confounding or residual variables have a normal distribution. If this normality test is violated, the statistical test will be invalid for a small number of samples. The results of the data normality test can be seen in the Table below:

Table 2. Normality Test of Kolmogorov Smirnov

\begin{tabular}{|l|l|l|}
\hline \multicolumn{2}{|l|}{ One-Sample Kolmogorov-Smirnov Test } \\
\hline \multicolumn{2}{|c|}{} & $\begin{array}{l}\text { Unstandardized } \\
\text { Residual }\end{array}$ \\
\hline Normal Parameters ${ }^{\text {a,b }}$ & Mean \\
\cline { 2 - 3 } & $\begin{array}{l}\text { Std. } \\
\text { Deviation }\end{array}$ &, 0000000 \\
\hline \multirow{2}{*}{$\begin{array}{l}\text { Most Extreme } \\
\text { Differences }\end{array}$} & Absolute &, 143 \\
\cline { 2 - 3 } & Positive &, 143 \\
\cline { 2 - 3 } & Negative &,- 074 \\
\hline Kolmogorov-Smirnov Z &, 927 \\
\hline Asymp. Sig. (2-tailed) &, 357 \\
\hline a. Test distribution is Normal. \\
\hline b. Calculated from data. \\
\hline
\end{tabular}

The Kolmogorov Smirnov normality test results show a significant value of 0.357 $>0.05$. Thus, the Kolmogorov Smirnov normality test results can be concluded that the data is normally distributed.

\section{Multicollinearity Test}

The multicollinearity test aims to test whether the regression model finds a correlation between the independent variables. In a good regression model there should be no correlation between the independent variables. Multicollinearity testing is done by looking at the VIF between the independent variables.

Table 3. Multicollinearity Test

\begin{tabular}{l} 
Table 3. Multicollinearity Test \\
\begin{tabular}{|l|l|l|l|}
\hline \multicolumn{2}{|l|}{ Coefficients ${ }^{\text {a }}$} \\
\hline \multirow{2}{*}{ Model } & Collinearity Statistics \\
\cline { 2 - 4 } \multicolumn{2}{|c|}{1} & Tolerance & VIF \\
\cline { 2 - 4 } & DER &, 933 & 1,072 \\
\cline { 2 - 4 } & CR &, 936 & 1,069 \\
\hline \multirow{2}{*}{ a. Dependent Variable: StockReturns } & 1,137 \\
\hline
\end{tabular} \\
\hline
\end{tabular}

The tolerance value for the variable return on equity, debt to equity ratio and current ratio was above 0.10 , while the VIF value of the return on equity, debt to equity ratio and current ratio was below 10 . Thus, the results of the multicollinearity test did not occur regression between independent variables.

\section{Autocorrelation Test}

There were 5 decisions in Durbin Watson's decision:

1. If $0<\mathrm{d}<\mathrm{dl}$, then there is positive autocorrelation 
Fenny et.al. Effect of return on equity, debt to equity ratio and current ratio to stock returns in large trading companies listed on the Indonesia stock exchange 2016-2018 period.

2. If $\mathrm{dl} \leq \mathrm{d} \leq \mathrm{du}$, it cannot be concluded that there is positive autocorrelation.

3. If 4 -dl $<\mathrm{d}<4$, then there is negative autocorrelation
4. If $4-\mathrm{du} \leq \mathrm{d} \leq 4-\mathrm{dl}$, then it cannot be concluded that there is negative autocorrelation.

5. If $d u<d<4-d u$, there is no positive or negative autocorrelation.

Table 4. Autocorrelation Test

\begin{tabular}{|l|l|l|l|l|l|}
\hline \multicolumn{5}{|l|}{ Model Summary } \\
\hline Model & R & R Square & Adjusted R Square & Std. Error of the Estimate & Durbin-Watson \\
\hline 1 &, $441^{\text {a }}$ &, 194 &, 131 &, 414880 & 2,022 \\
\hline a. Predictors: (Constant), CR, DER, ROE \\
\hline
\end{tabular}

Source: Data Processing Results

The Durbin-Watson test results showed a value of 2.022; whereas in the DW table for "k" = $3(\mathrm{k}=$ number of independent variables) and $\mathrm{N}=42$, the value of dl (lower limit) $=1.3573$ and $\mathrm{du}$ (upper limit) $=1.6617 ; 4-\mathrm{dl}=2.6427$ and 4 - $\mathrm{du}=2.3383$. By looking at the criteria in the Durbin-Watson guideline, the value of $\mathrm{du}<\mathrm{dw}<4$-du or $1.6617<2.022<2.383$, then from the results of the autocorrelation test it can be concluded that there is no positive and negative autocorrelation.

\section{Heteroscedasticity Test}

Detection of the presence or absence of heteroscedasticity can be done using the Glejser Test method, namely by regressing the absolute residual value on the independent variable.

The results of the Glejser test data in Table 5 above show that the significant value of the 3 independent variables is greater than 0.05 . Thus, the results of the Glejser test can be concluded that there is no heteroscedasticity problem.

Table 5. Heteroscedasticity Test

\begin{tabular}{|c|c|c|c|c|c|c|}
\hline \multicolumn{7}{|c|}{ Coefficients $^{\mathrm{a}}$} \\
\hline \multirow{2}{*}{\multicolumn{2}{|c|}{ Model }} & \multicolumn{2}{|c|}{ Unstandardized Coefficients } & \multirow{3}{*}{$\begin{array}{l}\text { Standardized Coefficients } \\
\text { Beta }\end{array}$} & \multirow{3}{*}{$\begin{array}{l}\mathbf{t} \\
1,673 \\
\end{array}$} & \multirow{3}{*}{$\begin{array}{l}\text { Sig. } \\
, 103 \\
\end{array}$} \\
\hline & & B & Std. Error & & & \\
\hline \multirow[t]{4}{*}{1} & (Constant) & ,164 & ,098 & & & \\
\hline & ROE & 844 & 515 &, 265 & 1,640 &, 109 \\
\hline & DER & 018 & ,040 & ,073 & ,452 & 654 \\
\hline & CR & 003 & ,006 & 090 & ,539 & ,593 \\
\hline
\end{tabular}

Hypothesis testing used in this study is to use multiple linear regression analysis. The regression model used is as follows:

Table 6. Regression Equations

\begin{tabular}{|c|c|c|c|c|c|c|}
\hline \multicolumn{7}{|c|}{ Coefficients $^{\mathrm{a}}$} \\
\hline \multirow{2}{*}{\multicolumn{2}{|c|}{ Model }} & \multicolumn{2}{|c|}{ Unstandardized Coefficients } & \multirow{2}{*}{$\begin{array}{l}\text { Standardized Coefficients } \\
\text { Beta }\end{array}$} & \multirow[t]{2}{*}{$\mathbf{t}$} & \multirow[t]{2}{*}{ Sig. } \\
\hline & & B & Std. Error & & & \\
\hline \multirow[t]{4}{*}{1} & (Constant) &,- 354 &, 158 & & $-2,237$ & ,031 \\
\hline & ROE & 1,692 & ,832 & ,307 & 2,034 &, 049 \\
\hline & DER & 137 & ,065 & ,319 & 2,122 &, 040 \\
\hline & $\mathrm{CR}$ & 016 & 010 & 248 & 1,598 &, 118 \\
\hline
\end{tabular}

\section{Stock Returns $=-0,354+1,692 \mathrm{ROE}+$ 0,137DER + 0,016CR}

The meaning of the multiple linear regression equation above is:

1. A constant of -0.354 states that if the return on equity, debt to equity ratio and current ratio are constant, the stock returns is -0.354 units.
2. The return on equity regression coefficient of 1.692 states that each 1 unit increase in return on equity will lead to an increase in stock returns of 1.692 units.

3. Debt to equity ratio regression coefficient of 0.137 states that each increase in debt to equity ratio 1 unit 
will cause an increase in stock returns of 0.137 units.

4. Current ratio regression coefficient of 0.016 states that each increase in current ratio 1 unit will cause an increase in stock returns of 0.016 units.

\section{Effect of Return on Equity on Stock Returns}

From the calculation results, it is obtained that the $t$ value of return on equity is 2.034 with a significant value of 0.049 . The value of tcount > ttable or $2.034>$ 2.02439 thus the results of this study are in line with $\mathrm{H} 1$ because Return on Equity has a positive and significant effect on stock returns in large trading sub-sector companies listed on the Indonesia Stock Exchange in the 2016-2018 period.

\section{Effect of Debt to Equity Ratio on Stock Returns}

From the results of data processing, it is obtained that the $t$ value of debt to equity ratio is 2.122 with a significant value of 0.040 . The value of tcount $>$ ttable or $2.122>2.02439$ thus the results of this study are in line with $\mathrm{H} 2$ because the Debt to Equity Ratio has a positive and significant effect on stock returns in large trading sub-sector companies listed on the Indonesia Stock Exchange in the 2016-2018 period.

\section{Effect of Current Ratio on Stock Returns}

From the calculation results obtained $\mathrm{t}$ value of current ratio of 1.598 with a significant value of 0.118 . The value of tcount $<$ ttable or $1.598<2.02439$ thus the results of this study are not in line with H3 because the current ratio has no effect on stock returns in large trading sub-sector companies listed on the Indonesia Stock Exchange in the 2016-2018 period.

\section{CONCLUSION AND SUGGESTION Conclusion}

The conclusions from the results of this study are:
1. Return on equity has a positive and significant effect on stock returns. If the ROE value increases, it will increase the value of the stock return in large trading sub-sector companies listed on the Indonesia Stock Exchange in the 20162018 period.

2. Debt to equity ratio has a positive and significant effect on stock returns. If the DER value increases, it will increase the share return value in large trading subsector companies listed on the Indonesia Stock Exchange in the 2016-2018 period.

3. Current ratio has no significant effect on stock returns. If the value of the current ratio increases, it does not affect the return of shares in large trading subsector companies listed on the Indonesia Stock Exchange in the 2016-2018 period.

\section{Suggestion}

Suggestions from the results of this study are:

1. For companies, to pay more attention to the ratios that can increase the rate of return on shares or stock returns. Like the ROE ratio, a large trading company must be able to increase the ROE value of its company, for example by increasing sales without increasing operational expenses and costs, or in other words, the company must be able to increase sales efficiency. You can also reduce the cost of goods sold or the company's operating expenses by sorting/replacing/repairing damaged equipment. That way the company's operating expenses will be more or less reduced. By increasing the ROE ratio, it will have an effect on the increase in stock purchases which will later have an effect on the increase in stock returns. Then large trading companies must also pay attention to the DER ratio where high debt must be managed properly so that it can generate high profits as well. Because high profits can affect the increase in stock prices and stock 
returns. Large trading companies can continue to increase the DER value to increase their operations, but the increase in DER value can be done until the company's welfare is not disturbed. For this reason, companies must be careful in increasing the DER value.

2. For investors, before making a decision to invest in a large trading sub-sector company, you should pay attention to the overall financial performance because based on the research results, the current ratio variable cannot be used as a determining indicator for the amount of stock return, while the return on equity and debt to equity ratio variables can be used. Affect the value of stock returns because high profits will also have an impact on increasing shareholder income. Likewise, high debt to equity does not always have a negative impact on the company because if the debt can be managed properly it will provide benefits for the company and increase stock returns in large trading sub-sector companies listed on the Indonesia Stock Exchange.

3. For further researchers, it is suggested as reference material for further research to add different research variables such as price earning ratio, price book value, dividend payout ratio and others.

\section{Acknowledgement: None}

\section{Conflict of Interest: None}

\section{Source of Funding: None}

\section{REFERENCES}

1. Aisah, Ayu Nurhayani \& Kastawan Mandala. 2016. "Pengaruh Return on Equity, Earning Per Share, Firm Size, dan Operating Cash Flow Terhadap Return Saham". Universitas Udayana (Unud), Bali.

2. Agramaya. 2017. "Analisis Faktor-faktor yang Mempengaruhi Nilai Current Ratio pada PT Tiga Pilar Sejahtera Food, Tbk Periode 2010-2015”. Fakultas Ekonomi dan Ilmu Sosial Universitas Baktri.
3. Alipudin, Asep \& Resi Oktaviani. 2016. "Pengaruh EPS, ROE, dan DER terhadap Harga Saham pada Perusahaan Sub Sektor Semen yang Terdaftar di BEI". Fakultas Ekonomi Universitas Pakuan.

4. Anugrah, Agung \& Muhamad Syaichu. 2017. "Analisis Pengaruh Return on Equity,Debt to Equity Ratio, Current Ratio, dan Price to Book Value terhadap Return Saham Syariah". Fakultas Ekonomika dan Bisnis Universitas Diponegoro.

5. Amrah, Rosa Yuminisa \& Elwisam. 2018. "Pengaruh Current Ratio, Return on Assets, Debt to Equity Ratio dan Total Assets Turn Over Terhadap Harga Saham Pada Perusahaan LQ45 Tahun 2013-2015”. Jurnal Ilmu Manajemen, Universitas Nasional.

6. Bahsalama, Ihsan S, Sri Murni, \& Jacky S.B. Sumarauw. 2017. "Pengaruh Current Ratio, DER, dan ROA terhadap Return Saham Pada Perusahaan Otomotif dan Komponen Periode 2013-2015”. Universitas Sam Ratulangi, Manado.

7. Batubara, Hade Chandra. 2017. "Pengaruh ROA, ROE, dan DER Terhadap Harga Saham Pada Perusahaan Makanan dan Minuman yang Terdaftar di Bursa Efek Indonesia Periode 2011-2015". Universitas Muhammadiyah Sumatera Utara.

8. Choiriah, Aprillia Nur, Ronny Mallavia M \& Budi Wahono. 2017. "Analisis Pengaruh EPS, ROE, DER, dan CR Terhadap Harga Saham dengan PER sebagai Variabel Moderating". Fakultas Ekonomi Unisma.

9. Dewi, Putu Dina Aristya \& I.G.N.A Suaryana. 2013. "Pengaruh EPS, DER, dan PBV terhadap Harga Saham". Fakultas Ekonomi, Universitas Udayana, Bali, Indonesia.

10. Djamaluddin, Said, Jhesica Resiana \& Djumarno. 2018. "Analysis the Effect of NPM, DER and Per On Return Share of Listed Company in Jakarta Islamic Index (JII) Period 2011-2015". International Journal of Business and Management Invention (IJBMI).

11. Eliana. 2017. "Pengaruh Return on Equty terhadap Return Saham (Studi Pada Perusahaan Manufaktur Periode 2012-2015 di Bursa Efek Indonesia)". Sekolah Tinggi Ilmu Ekonomi Sabang, Banda Aceh.

12. Elvira, Nina Felicia. 2019. "Pengaruh Current Ratio, Debt to Equity Ratio, Return on Asset, Earning Per Share terhadap 
Fenny et.al. Effect of return on equity, debt to equity ratio and current ratio to stock returns in large trading companies listed on the Indonesia stock exchange 2016-2018 period.

Return Saham dan Risiko Sistematis Pada Perusahaan Sektor Infrastuktur, Utilitas, Transportasi yang Terdaftar di Bursa Efek Indonesia Tahun 2013-2018". Fakultas Manajemen, Universitas Pasundan Bandung, Indonesia.

13. Erari, Anita. 2014. "Analisis Pengaruh Current Ratio, Debt to Equity Ratio, dan Return on Asset Terhadap Return Saham Pada Perusahaan Pertambangan di Bursa Efek Indonesia". Fakultas Ekonomi Universitas Cendrawasih.

14. Febrioni, Rio. 2016. "Pengaruh Return on Assets, Return on Equity, Earning Per Share, dan Current Ratio terhadap Return Saham Pada Perusahaan yang Terdaftar di Indeks LQ45 di Bursa Efek Indonesia Tahun 2011-2015". E Proceeding of Management.

15. Ghozali, Imam. 2013. Analisis Multivariate Program IBM SPSS 21. Ed.7, Semarang: Badan Penerbit Universitas Diponegoro.

16. Purnamasari, Khairani, Emrinaldi Nur DP, \& Raja Ardi Satriawan S. 2014. "Pengaruh Current Ratio, Debt to Equity Ratio, Return on Equity Ratio, Price Earning Ratio, dan Earning Per Share terhadap Return Saham Pada Perusahaan Property and Real Estate yang Terdaftar di Bursa Efek Indonesia Periode 2009-2011”. Kampus Pattimura Gobah, Pekanbaru.

17. Rosikah, Dwi Kartika Prananingrum, Dzulfikri Azis Muthalib, Muh. Irfandy Azis, \& Miswar Rohansyah. 2018. "Effects of Return on Asset, Return on Equity, Earning Per Share on Corporate Value". The International Journal of Engineering and Science (IJES).

18. Sugiarti, Surachman, \& Siti Aisjah. 2015. "Pengaruh Kinerja Keuangan PerusahaanTerhadap Return Saham (Studi Pada Perusahaan Manufaktur yang
TerdaftardiBursa Efek Indonesia)". Fakultas Ekonomi dan Bisnis Universitas Brawijaya.

19. Sugiyono. 2017. Metode Penelitian Pendidikan. Bandung: CV. Alfabeta.

20. Sujarweni, V. Wiratna. 2014. Metodologi Penelitian. Yogyakarta: Pustaka Baru Press.

21. Supriantikasari, Novita \& Endang Sri Utami. 2019. "Pengaruh Return on Assets, Debt to Equity Ratio, Current Ratio, Earning Per Share, dan Nilai Tukar Terhadap Return Saham (Studi Kasus Pada Perusahaan Go Public Sektor Barang Konsumsi yang Listing Di Bursa Efek Indonesia Periode 2015-2017)". Fakultas Ekonomi, UMB Yogyakarta.

22. Suryawan, I Dewa Gede \& I Gde Ary Wirajaya. 2017. "Pengaruh Current Ratio, Debt to Equity Ratio, dan Return on Assets pada Harga Saham". E-Journal Akuntansi Universitas Udayana.

23. Tumonggor, Mutiara, Sri Murni, \& Paulina Van Rate. 2017. "Analisis Pengaruh Current Ratio, Return on Equity Ratio, dan Growth terhadap Return Saham Pada Cosmetics and Household Industry yang Terdaftar di BEI Periode 2010-2016". University of Sam Ratunglagi Manado.

24. Utami, Martina Rut, \& Darmawan Arif. 2019. "Effect of DER, ROA, ROE, EPS and MVA on Stock Price in Sharia Indonesia Stock Index". Managerial Accounting, Politeknik Negri Batam.

25. Wira, Desmond. 2019. Analisis Fundamental Saham. Edisi Kegita, Exceed.

How to cite this article: Fenny, Edward YR. Effect of return on equity, debt to equity ratio and current ratio to stock returns in large trading companies listed on the Indonesia stock exchange 2016-2018 period. International Journal of Research and Review. 2021; 8(5): 389-396. DOI: https://doi.org/10.52403/ijrr. 20210548 